ELORE (ISSN 1456-3010), vol. 15 - 2/2008.

Julkaisija: Suomen Kansantietouden Tutkijain Seura ry.

[http://www.elore.fi/arkisto/2_08/hot2_08.pdf]

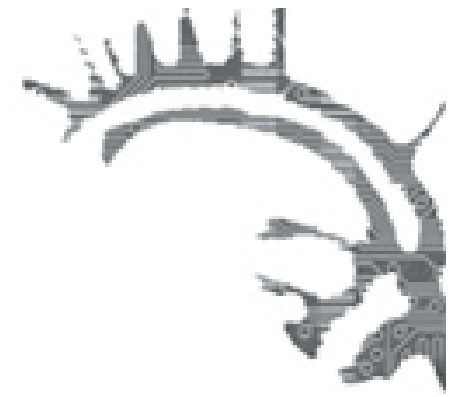

\title{
KIRJA-ARVIO: \\ TASA-ARVOISEN JA LUOKATTOMAN YHTEISKUNNAN UUDET LUKUTAVAT
}

Tolonen, Tarja (toim.) 2008: Yhteiskuntaluokka ja sukupuoli. Tampere: Vastapaino. 301 sivua.

\section{$\underline{\text { Tuija Hovi }}$}

Kulttuuriantropologi Katriina Järvinen ja historioitsija Laura Kolbe (2007) ehtivät avaamaan keskustelun yhteiskuntaluokan uudesta tulemisesta tutkimuskentille puhuttelevilla esseillään. Vastikään ilmestynyt Ybteiskuntaluokeka ja sukupuoli-artikkelikokoelma problematisoi aihetta erilaisten tutkimusaineistojen kautta. Tärkeä vaikuttaja uudelle luokkatutkimukselle on ollut ranskalainen sosiologi Pierre Bourdieu, jonka teoreettista antia suomalaiselle yhteiskuntatieteelle käsittelevän teoksen esittelin edellisessä Eloren numerossa. Kyselin silloin Bourdieun kulttuuriteorioiden antropologisten ja naistutkimuksellisten sovellusten ja arvioiden perään. Voilá! Tarja Tolosen toimittamassa artikkelikokoelmassa erityisesti jälkimmäinen toivomukseni on toteutunut. Bourdieun keskeisyys feministisessä luokkakeskustelussa suodattuu esiin useissa kirjan artikkeleissa erityisesti Beverley Skeggsin kritiikin kautta. Bourdieuta on kritisoitu siitä, että hän aliarvioi sukupuoliset prosessit teorioissaan. Silti hänen käsitteensä habitus, pääoma, kenttä, tyyli, maku ja distinktio hyödyttävät myös sukupuolitietoista kulttuurin ja yhteiskunnan tutkimusta.

Kokoelman kirjoittajia yhdistää naistutkimusintressi. Mukana on vahva sosiologiedustus, mutta pyrkimyksenä on ollut keskusteluttaa muitakin tieteenaloja. Niitä kaikkiaan 12 artikkelin kokoelmassa edustavat psykologian, historian, kasvatustieteen ja folkloristiikan näkökulmat. Laajempina teema-alueina ovat luokan, sukupuolen ja materian suhde, seksuaalisuus ja rajat, perheessä rakentuvat erot, koulutus ja työelämään siirtyminen. Avausartikkelissaan Tarja Tolonen pohjustaa kirjan teemoja jäljittämällä yhteiskuntaluokan tutkimuksen paradigman muutosta. Staattinen luokan käsite on saanut dynaamisemman käsittelyn Britanniassa nousseen uuden luokkatutkimuksen myötä. Bourdieun annin naistutkimukselle Tolonen määrittelee siten, että siinä yhdistyy 
luokka-analyysi kulttuurintutkimukseen tavalla, joka jättää tilaa naisten kokemuksen tutkimiselle. Kirjoittajat ovat halunneet osoittaa luokan monimuotoisuuden sekä sen rakenteiden näkyvyyden arjen kulttuurisissa käytänteissä. Yhtenäisen teoriapohjan takia artikkeleissa ei ole aivan voitu välttää toistoa.

\section{SUKUPUOLEN, SEKSUAALISUUDEN JA NORMAALIN PERHEEN RAKENTUMINEN}

Tuula Gordonin artikkeli materialistisesta feminismistä on kirjan teoreettisinta antia. Hän kuljettaa lukijaa marxilaisesta realismista sitä kritisoivan kulttuurisen käänteen kautta feministiseen kulttuuris-poliittis-sosiaaliseen lähestymistapaan. Sillä tiellä hän on etsinyt tapoja tutkia halujen ja toiveiden materialistisuutta. Omassa etnografisessa tutkimuksessaan Gordon on kollegoineen tarkastellut tilan, liikkeen ja äänen kontrollia koulumaailmassa ja huomioinut erityisesti näiden järjestysten sukupuolittuneita piirteitä. Kieli ja diskurssit asemoivat subjektit ja tuottavat heidän kokemuksensa. Kokemus kulttuurisesti rakentuneena ja tulkittuna on Gordonin mukaan sekä kielellinen että materiaalinen tapahtuma.

Seksuaalisuutta ja rajoja pohtivat Sanna Aaltonen ja Niina Lappalainen omissa artikkeleissaan. Aaltosen aiheena on tyttöjen tulkinnat sukupuolisesta häirinnästä. Tutkimusta varten yhdeksäsluokkalaisten parissa kerätyissä ainekirjoituksissa elämäntyyli, ulkonäkö ja varakkuus nousevat habituksena tyyliä ja yhteiskuntaluokkaa merkitseviksi tekijöiksi. Nuorten käsitykset keskiluokkaisuudesta ja työväenluokkaisuudesta ovat tasapuolisen konservatiivisia ja determinoituja erityisesti suhteessa tyttöjen seksuaalisuuteen. Ulkopuolisten osallistuminen naisen maineen määrittelyyn sisältyy olennaisesti myös Niina Lappalaisen tutkimukseen, jossa pohdinnan kohteena on maineen ja uskottavuuden arviointi aikuisten työyhteisössä. Aineistona hänen tutkimuksessaan on muistelukerronta ja hurtti seksuaalihuumori, joissa välittyy tietoa myös luokasta ja sukupuolesta. Lappalainen kysyy, toteutuuko tasavertaisuus sukupuolten välillä hauskanpidossa. Nonkommunikaatiolla eli ilmaisemattomuudella ohitetaan hierarkia ja epätasa-arvo. Niistä ei haluta puhua suoraan, sen sijaan niihin uskalletaan viitata leikkimielisessä puheessa.

Minna Kelhä tarkastelee artikkelissaan äitiyden luokan ja iän suhdetta. Tätä varten hän on haastatellut 24 eri-ikäistä ensi kertaa äidiksi tullutta naista. Osa haastateltavista määritteli itsensä joko työväenluokkaiseksi tai keskiluokkaiseksi, osan kirjoittaja määritteli itse sosiaalisista taustoista saamiensa tietojen perusteella. Yhteiskuntaluokka näyttäytyy Kelhän aineistossa toisiinsa liittyvinä suhteina, jotka hän määrittelee suhteiksi perheeseen, asiantuntijatietoon sekä rahaan ja toimeentuloon. Olennaisesti uutta lähestymistapaa osoittava huomio on se, että yhteiskuntaluokka ei ole staattinen vaan rakentuu kontekstuaalisesti. Luokka rakentuu yksilöllisistä valinnoista myös Mari Käyhkön aineistossa. Hänen tutkimuskohteenaan ovat olleet nuoret siivoojiksi kouluttautuvat naiset. Luokkatietoisuus välittyi heidän asenteistaan, joihin ei liittynyt halua "oikeisiin" eli hallitsevan luokan valintoihin. Kuten Käyhkö 
toteaa, kasvaminen työväenluokkaisen kulttuurin jäseneksi on sen merkityskarttojen, arvostusten ja maailmassa olemisen tapojen oppimista. Samalla lailla naiseksi kasvamista ohjaavat erilaiset kulttuuriset käsikirjoitukset, joita ovat yksilön luokkataustaan sitoutuvat kulttuuriset mallit, ihanteet ja odotukset naisena elämisestä. Äitiys toimi myös pakopaikkana niille, jotka eivät olleet halukkaita itsenäisiin valintoihin vaan halusivat pikemminkin rakentaa itseään toisten kautta.

Katja Yesilova analysoi artikkelissaan terapeuttisen perhetyön kieltä ja kulttuuria. Hän etsii terapiakielestä tunnustuksen ja itsen välistä kytköstä ja tarkastelee itsestä kertomisen konteksteja eri yhteiskuntaluokissa. Luokkia on, kuten muissakin kirjan tutkielmissa, kaksi: keskiluokka ja työväenluokka. Niiden alaluokat ja luokkien sisäiset kategoriat kuitenkin moninaistavat kenttää, johon kohdistuva perhetyö perustuu porvarillisuus-ihanteeseen. Sen mukaan määrittyy terapiatyötä ohjaava keskimääräisyys eli normaalius. Kyvyttömyys tai haluttomuus tunnustuspuheeseen pudottaa terapiaasiakkaat hegemonisesta tavallisuudesta nopeasti. "Keskivertoperhe" kyseenalaistuu niin ikään Maija Urposen artikkelissa, joka käsittelee monikulttuurisia parisuhteita ja suomalaisessa julkisuudessa syntyneitä sukupuolittuneita kuvia yhteiskuntaluokista. Suomalainen keskiluokkaisuus näyttäytyy hänenkin analyysissään hegemoniana, jota monikulttuurisuus rikkoo ja johon sitä verrataan. Luokka ei aina esiinny ääneen lausuttuina henkilökohtaisina tai kollektiivisina luokkaidentiteetteinä, vaan sen läsnäolo on huomaamattomampaa. Silti se on monikulttuurisille pareille merkittävä tekijä.

\section{KOULU, TYÖ JA VAPAA-AIKA YHTEISKUNTALUOKAN MERKKEINÄ}

Saara Tuomaala on tutkinut kansakoulun jälkeistä jatko-opetusta 1900-luvun punavalkoisessa Suomessa. Näillä jatkokursseilla oli tarkoitus syventää kahden vuoden ajan maalaisnuorten tietoja maaseudun elinkeinoista, elleivät he hakeutuneet kansakoulun jälkeen esimerkiksi ammatilliseen koulutukseen. Tuomaala kytkee luokittain ja sukupuolittain jakautuneen koulunkäynnin laajempaan kysymykseen suomalaisuushankkeesta, jossa avainasemassa nähtiin olevan kansalaiskasvatus ja kansanvalistus. Oppivelvollisuuden ja jatko-opintojen käytäntöihin sisältyi voimakkaita lasten ja nuorten välisiä erotteluita, jotka kytkeytyivät paikallisuuden lisäksi luokka-asemaan, sukupuoleen, politiikkaan, etnisyyteen ja terveyteen.

Katri Komulainen, Hannu Räty ja Maija Korhonen tarkastelevat nykynuorten kuvitelmia yrittäjyydestä. Tuomaalan aineistoon verrattuna agraarityön ihanne on korvautunut yrittäjyydellä. Opetusministeriön toimenpideohjelman suunnitelman mukainen yrittäjyys näyttäytyy sukupuolettomana ja kaikille kansalaisille kuuluvana mahdollisuutena. Historiallisesti yrittäjyys on kuitenkin ollut keskiluokkainen ja maskuliininen konstruktio. Kirjoittajat analysoivat yrittäjäminuutta ja siihen liittyviä sukupuoli- ja luokkaeroja nuorilta kerätyssä kilpakirjoitusaineistossa. He huomauttavat aiheellisesti, että kilpa-aineet eivät heijasta nuorten kuvitelmia minuuksistaan sellaisenaan, vaan ne ovat suodattuneet odotusten ja kulttuuristen konventioiden mukaisiksi. Teksteissä näkyy sukupuolittunut tapa hahmottaa yrittäjyys. Siinä heijastuu edelleen 
konservatiivinen yrittäjäminän hyve keskiluokkaisena maskuliinisuutena, kun taas naiseus, työväenluokkaisuus ja palkkatyöläisyys näyttävät puolestaan kuuluvan yhteen. Silmiinpistävä piirre suomalaisessa yrittäjäkasvatuskulttuurissa on nuorten teksteistä välittyvä talonpoikaisaskeettinen viesti: yrittäminen on sallittu mutta menestyminen ei!

Tarja Tolonen on tahollaan analysoinut laadullista haastatteluaineistoa tutkiessaan nuorten elämäntyylejä ja luokkaeroja. Avainsanoina ovat jälleen sosiaaliset kentät ja pääomat, joiden kautta luokan ja kulttuurin sekä elämäntavan ja tyylin kysymykset nousevat esiin. Puheenaiheina ovat syrjäytymiseen, pärjäämiseen ja menestymiseen liittyvät ilmaukset. Oletuksena on, että perheen arvostukset ja kulttuuripääoma periytyy lapsille habituksen kautta. Tolosen tavoitteena on ollut osoittaa, miten suomalaisessa tasa-arvoa ja tavallisuutta korostavassa kulttuurissa on mahdollista löytää yhteiskuntaluokkaan viittaavia erotteluja. Työväenluokkaisuuden ja keskiluokkaisuuden leimat tulevat ilmi puhujien suhteessa pärjäämiseen ja menestymiseen ja siihen, mikä on toivottavaa ja sallittua itse kullekin. Viesti on hyvin samansuuntainen kuin Komulaisen ja kumppaneiden yrittäjäminää kartoittavassa kilpakirjoitusaineistossa.

Päivi Berg on tutustunut etnografian keinoin koululiikuntaan ja nuorten liikuntaharrastuksiin. Sukupuolen ja yhteiskuntaluokan rajat piirtyvät esiin silläkin kentällä, kun lasten liikuntaa ohjaa usein vanhempien varallisuus. Berg on teoretisoinut aineistoaan fyysisen pääoman käsitteellä. Fyysisillä aktiviteeteilla hankittuihin kykyihin ja mahdollisuuksiin liittyy symbolinen arvostus tietyillä kentillä. Ruumiillistuneen pääoman kirjoittaja tulkitsee yhtenä kulttuurisen pääoman muotona. Kilpailuhenkinen koululiikunnan kenttä perustuu hierarkkisiin järjestyksiin, joille on haettu malli kilpaurheilusta. Kilpaurheiluihanne tuntuu myös tukevan enemmän poikien kuin tyttöjen liikuntaharrastusta, mutta vapaa-aikakin on tärkeä sosiaalisen identiteetin määrittelijä. Ero muodostuu niiden lasten välille, jotka harrastavat liikuntaa omaehtoisesti, koska saavat siitä mielihyvää ja niiden, joilla on mahdollisuus käyttää liikuntaa lisätäkseen vaihtoarvoaan.

\section{LUOKAT YHTEISKUNTIEN VERKOSTOSSA}

Kirjan päätösartikkelissa Lena Näre on ottanut käyttöön käsitteen ylirajaiset hoivaverkostot tutkiessaan puolalaisten naisten työllistymistä kodinhoitajina Napolissa. Tutkiessaan puolalaisnaisten ristiriitaisia työkokemuksia kahden maan välillä Näre on tullut siihen johtopäätökseen, että siirtolaisten kodinhoitotyö on pakostakin muuttanut luokkarakennetta. Hän päätyy siihen johtopäätökseen, että globaalien eriarvoisuuksien maailmassa tuotetaan palvelijayhteiskuntaa. Moderni "maailmankylä" siis ylläpitää konservatiivisia luokkahierarkioita.

Yhteiskuntaluokka ja sukupuoli-kirjan luokkina ovat keskiluokkaisuus-porvarillisuus ja työväenluokkaisuus. Sanna Aaltosen huomio siitä, kuinka keskiluokkaisuuskäsitteellä oletetaan olevan yhteisesti tunnettu merkitys, sopinee myös pieneksi kritiikiksi tieteellistä artikkelikokoelmaa kohtaan. Niin kutsuttu yläluokkaisuus ei sisälly kirjan 


\section{TUIJA Hovi}

pohdintoihin lainkaan, mikä kuvastanee suomalaisen yhteiskunnan "tasalaatuisuutta". Luokkajako ja sen variaatiot liikkuvat artikkeleissa jatkumolla syrjäytyneet-ylempi keskiluokka. Ehkä luupin alle saadaan tulevaisuudessa myös yläluokkaan lukeutuvien, mikäli sellaisia tänä päivänä Suomessa on, asema ja suhde yhteiskuntaan. Verrokkijoukkoa löytyy lähistöltä. Hiljattain suomeksi ilmestyneissä omakohtaisissa esseissään Alexander von Schönburg (2007) pohtii eurooppalaisen aristokratian "pokan pitämistä" merkittävän luokkaa rajaavan tekijän, suvun varallisuuden häviämisestä huolimatta. Hänenkin näkemyksensä olisivat tosin voineet hyötyä Bourdieun tyylin ja maun teorioista sekä varsinkin Skeggsin sukupuolisensitiivisestä kritiikistä.

Suomalaisen yhteiskuntaluokan, sukupuolen ja kulttuurin värikäs uusi kudos on nyt kuitenkin pantu alkuun. Kuteita sekä loimia löytyy varmasti ajan mittaan lisää, kun perinnetieteilijätkin innostuvat tematiikasta laajemmin.

\section{KiRjallisuUs}

JÄRVINEN, KATRIINA \& KOLBE, LAURA 2007: Luokkaretkellä byvinvointiybteiskunnassa: nykeysukupolven kokemuksia tasa-arvosta. Helsinki: Kirjapaja.

VON SCHÖNBURG, ALEXANDER 2007: Tyylikkään köybäilyn taito. Jyväskylä: Atena. [2005]

Filosofian tohtori Tuija Hovi on turkulainen uskontotieteilijä. 